\title{
Sztuczne sieci neuronowe i teledetekcja w ocenie porażenia pszenicy jarej fuzariozą kłosów
}

\author{
Artificial neural networks and remote sensing in the assessment of spring wheat \\ infection by Fusarium head blight
}

\section{Wiesław Golka ${ }^{1}$, Edward Arseniuk ${ }^{2}$, Adrian Golka ${ }^{3}$, Tomasz Góral ${ }^{4}$}

\author{
1 Instytut Technologiczno - Przyrodniczy, Falenty, Al. Hrabska 3, 05-090 Raszyn, \\ 2, 4 Instytut Hodowli i Aklimatyzacji Roślin - Państwowy Instytut Badawczy, Radzików, 05-870 Błonie, \\ ${ }^{3}$ Relayonit sp. z o.o., ul. Cietrzewia 23, 02-492 Warszawa,
}

\begin{abstract}
Celem prac badawczych było wykorzystanie teledetekcji oraz sztucznych sieci neuronowych w ocenie pszenicy jarej pod względem reakcji na fuzariozę kłosów wywoływaną przez grzyby z rodzaju Fusarium spp. Prace badawcze wykonano na roślinach 4 odmian pszenicy jarej. Były to: KWS Torridon i Izera - o wyższej odporności, Radocha i Nawra - o odporności niższej na ww. patogena. Wykonano zdjęcia zdrowych oraz porażonych kłosów wszystkich odmian, które następnie przetworzono przy użyciu programu Crops Vegetation Control Lab (CVC Lab.). Na podstawie uzyskanych obrazów utworzono ich reprezentacje w postaci sieci neuronowych Growing Neural Gas (GNG). W wyniku analizy zdjęć uzyskano 240 wzorców, z których wybrano po 6 bazowych wzorców choroby dla każdej odmiany. Następnie dokonano porównania próbek porażonych kłosów danej odmiany z bazowymi wzorcami chorobowymi tej samej odmiany pszenicy. W wyniku porównania wzorców roślin zdrowych i porażonych ze zdjęciami poletek roślin zdrowych i porażonych uzyskano zróżnicowanie wartości liczbowych dającej podstawę do konstrukcji mapy zdrowotności plantacji pszenicy z wyszczególnieniem ognisk choroby.
\end{abstract}

\begin{abstract}
Słowa kluczowe: fuzarioza kłosów, pszenica, sztuczne sieci neuronowe, teledetekcja
The aim of the research was to use remote sensing and artificial neural networks in the assessment of spring wheat in terms of response to infection of ears caused by fungi of the genus Fusarium spp. The research was carried out on plants of 4 varieties of spring wheat. They were: KWS Torridon and Izera - with higher resistance, Radocha and Nawra - with lower resistance to the pathogen. Pictures of healthy and infected ears of all varieties were taken, and then processed using the Crops Vegetation Control Lab (CVC Lab.) Program. Based on the obtained images, their representations in the form of Growing Neural Gas (GNG) neural networks were created. As a result of photo analysis, 240 patterns were obtained, out of which 6 basic disease patterns were selected for each variety. Next, a comparison of samples of infected ears of a given variety with baseline disease patterns of the same wheat variety was made. As a result of comparing healthy and diseased plant patterns with pictures of healthy and infested plant plots, a diversity of numerical values was obtained that gave rise to the construction of a wheat plantation map detailing spots with diseased plants.
\end{abstract}

Key words: Fusarium head blight, wheat, artificial neural networks, teledetection

\section{Wstęp}

W ostatnim 20-leciu nastąpił znaczny wzrost zainteresowania komputerową cyfrową analizą obrazu (DIA) oraz sztuczną inteligencją (AI). Zapewne ma to związek $\mathrm{z}$ olbrzymim postępem technicznym, jaki nastąpił w obszarach jakości i rozdzielczości sprzętu elektroniczno - optycznego, szybkości przesyłania danych, pojemności i mocy komputerów wykonujących obliczenia, oraz sztucznych sieci neuronowych mających m.in. zastosowanie w procesach identyfikacji obiektów. Wyniki badań jakie prowadzono w tych obszarach, zaczęto wdrażać do praktyki gospodarczej (Skulska i in. 2003). Początkowo obrazy z badanych obiektów przesyłano do urządzeń analogowych i przetwarzano do postaci cyfrowej. Następnie obraz przesyłano do komputera i dokonywano jego analizy (Frączek 2005). Podobną metodą prowadzono badania bryły glebowej odkształcanej wąskim narzędziem (Piotrowska 2003), a także badania dotyczące identyfikacji efektów mieszania gleby w procesie powierzchniowej uprawy (Łukawski i Golka 2011). Zważywszy, że termin „sztuczne sieci neuronowe, i model matematyczny neuronu pojawiły się w roku 1943 (Osowski 2000), a praca powodująca rozwój neuronowych sieci wielowarstwowych w roku 1986 (Rumelhart i McClelland 1986), czas „od pomysłu do przemysłu” był dość długi i był spowodowany oczekiwaniami 
Wiesław Golka, Edward Arseniuk, Adrian Golka...

na dalszy postęp techniczny. Sztuczne sieci neuronowe (SSN) posiadają zdolność do aproksymacji wartości funkcji wielu zmiennych, w odróżnieniu od interpolacji możliwej przy przetwarzaniu algorytmicznym. Czyni to je niezastąpionymi przy wielu nierozwiązywalnych dotychczas zadaniach a obszar ich zastosowań jest bardzo rozległy, w tym również w rolnictwie. Około 2000 roku na rynku zaczęły się pojawiać aplikacje technik neuronowych dla rolnictwa. Wykorzystując neuronową technikę rozpoznawania obrazu, maszyny mogły wykonywać pracę bez ingerencji człowieka. Oto kilka przykładów: maszyna do wyrywania chwastów, robot do monitoringu stanu pola i plonu, neurorobot do wykrywania oraz usuwania ślimaków, neurorobot czyszczący w budynkach inwentarskich (Boniecki 2005, Łuczycka 2016). W ostatnim dziesięcioleciu nastąpił na tym obszarze znaczący postęp. Większość dużych firm produkujących dla rolnictwa, oferuje wraz ze swoimi maszynami, zaawansowane technicznie aplikacje technik neuronowych. Do mapowania pól uprawnych zatrudniono już obecnie różne konstrukcje dronów. Zwiększenie jakości optyki przy jednoczesnej obniżce cen rynkowych w najbliższym czasie pozwoli na uzyskanie zdjęć o rozdzielczości $1 \mathrm{~mm}$ na punkt. Zdjęcia takie mają oczywiście olbrzymie rozmiary jako pliki, które muszą zostać poddane analizie. Z kolei, zdobywający popularność szybki internet mobilny LTE (Long Term Evolution) pozwala na ich transfer, a dyski SSD (solid-state drive) zapewniają miejsce dla danych i szybki do nich dostęp. Wszystko to wskazuje, że prognozy dotyczące zmian w rolnictwie precyzyjnym mają silne podstawy i w najbliższych latach możemy się spodziewać wielu ciekawych rozwiązań. Nastąpił zatem sprzyjający rozwojowi rolnictwa precyzyjnego czas robotyzacji rolnictwa. W ostatnich latach podjęto liczne prace nad zastosowaniem sztucznej inteligencji do planowania oprysków roślin środkami chemicznymi. Prace takie prowadzą m.in. John Deere, Bosch, Bayer, Blue River Technology. Celem badań jest prowadzenie oprysków ochronnych jedynie na fragmentach pól $\mathrm{z}$ porażonymi roślinami. Wykorzystanie sztucznych sieci neuronowych pozwala bowiem na identyfikację rozproszonych ognisk chorób na monitorowanych plantacjach. (Qiu i in. 2019, Jin i in. 2018, Yuan $i$ in. 2014). Do obrazowania chorób roślin wykorzystywane są różne techniki takie jak obrazowanie hiperspektralne, obrazowanie fluorescencyjne, w podczerwieni i świetle widzialnym (Sankaran $i$ in. 2010).

\section{Występowanie i szkodliwość chorób pszenicy i pszenżyta}

Najczęściej występującymi chorobami pszenicy w ostatnich latach były: rdza brunatna, mączniak prawdziwy, septorioza liści i plew, a także łamliwość źdźbła (Arseniuk i Góral 2015, Figueroa i in. 2018). W ostatnich latach wzrasta także znaczenie fuzariozy kłosów powodowanej przez grzyby z rodzaju Fusarium spp., co jest powiązane ze wzrostem powierzchni uprawy kukurydzy oraz monokulturą zbożową $(72,1 \% \mathrm{w}$ ogólnej powierzchni zasiewów w 2018 r.). Resztki pożniwne kukurydzy, która podatna jest na fuzariozę kolb są rezerwuarem inokulum grzybów Fusarium spp. porażającym pszenicę (Góral i in. 2015). Wzrasta również zagrożenie pszenżyta rdzą żółtą, dotychczas obserwowaną sporadycznie w uprawach pszenicy w Polsce. Przyczyną może być pojawienie się nowych agresywnych ras Puccinia striiformis, sprawcy tej choroby, oraz adaptacja patogena do wyższych temperatur występujących wiosną w Polsce (Hovmøller i in. 2015). Objawy rdzy żółtej obserwowane są przede wszystkim na liściach, ale występują również na plewach i ziarnie, szczególnie u pszenżyta. Do znacznych spadków plonu ziarna może prowadzić porażenie liścia flagowego u pszenicy lub kłosów u pszenżyta. Charakterystyczne dla rdzy żółtej jest występowanie w łanie pszenicy rozproszonych ognisk tej choroby, rozszerzających się w miarę postępu epifitozy.

Wzrasta znaczenie chorób wywoływanych przez patogeny nekrotroficzne do których należą grzyby z kompleksu Parastagonospora spp., Zymoseptoria tritici i inne grzyby porażające zielone organy roślin zbożowych. Gatunki te powodują chlorozy i nekrozy liści pszenicy i pszenżyta co na skutek degradacji chlorofilu prowadzi do ich przedwczesnego starzenia i zamierania. Powoduje to zmniejszenie powierzchni asymilacyjnej łanu skutkujące obniżeniem plonu. W sprzyjających warunkach grzyb Parastagonospora nodorum poraża kłosy prowadząc do spadku wartości siewnej ziarna. Znaczenie wywoływanej przez ten grzyb septoriozy liści i plew w uprawie pszenicy i pszenżyta wynika z niskiej lub średniej odporności na te choroby większości odmian uprawianych w Polsce (Arseniuk i in. 1991, Arseniuk i Góral 2015). Innym ujemnym efektem obserwowanym w ostatnich latach jest uodparnianie się grzyba Zymoseptoria tritici na niektóre substancje aktywne fungicydów np. fungicydów z grupy azoli (Dafne 250 EC) (Yang i in. 2013). Porażenie kłosów zbóż przez Fusarium spp. prowadzi do ilościowych i jakościowych strat 
w plonie ziarna. Efektem fuzariozy kłosa może być uszkodzenie zarodka (wstrzymanie rozwoju ziarniaka) lub obniżenie masy ziarniaków, pomarszczenie, osłabienie siły kiełkowania, zasiedlenie ziarniaków przez Fusarium spp. oraz zakażenie mikotoksynami fuzaryjnymi. Grzyby $\mathrm{z}$ rodzaju Fusarium porażające zboża posiadają zdolność do wytwarzania trichotecenów (deoksyniwalenol=DON, niwalenol), moniliforminy, zearalenonu oraz fumonizyn. Trichoteceny nie są obojętne dla zdrowia ludzi i zwierząt. Odporne na procesy przetwórcze mogą występować w artykułach żywnościowych i paszach produkowanych na bazie zbóż. Związki te mają silne działanie toksyczne objawiające się w postaci podrażnienia skóry, wymiotów, biegunki, osłabienia łaknienia, krwotoków. W przypadku silnych zatruć mogą występować zaburzenia neurologiczne, mogą prowadzić do poronień a nawet śmierci. Długotrwałe spożywanie przez ludzi DON-u i związków pochodnych zmniejsza odporność na choroby i osłabia system immunologiczny. Charakterystyczne dla fuzariozy kłosów jest występowanie w łanie pszenicy rozproszonych ognisk tej choroby w miejscach o sprzyjającym mikroklimacie np. obniżeniach terenu o większej wilgotności gleby (Niedbała i in. 2020, Arseniuk i Góral 2015, Góral i in. 2015, Prandini i in. 2009).

\section{Charakterystyka metod stosowanych w cyfrowej analizie obrazu badanych obiektów}

Uzyskane zdjęcia łanów roślin są podstawą do analizy histogramów długości fal, jak również do wyliczania na ich podstawie wskaźników pozwalających na ocenę zdrowotności upraw (Nieróbca $\mathrm{i}$ in. 2009, Pudełko i in. 2008, Alchanatis $\mathrm{i}$ in. 2005). Analiza spektrum światła widzialnego może służyć między innymi do wykrywania chwastów, np. w uprawach buraka cukrowego, ze skutecznością sięgającą 97\% (Kazmi i in. 2014, Perez i in. 2000). W naszych badaniach zostały wykorzystane zarówno zdjęcia wykonywane $\mathrm{w}$ zakresie bliskiej podczerwieni jak i w zakresie światła widzialnego.

Proponowana metoda zakłada zastosowanie algorytmów grupowania danych (analiza skupień) w celu identyfikacji i oznaczenia próbek. Anomalie występujące $\mathrm{w}$ zbiorach wejściowych pozwalają na wytworzenie map wzorcowych, charakterystycznych dla badanych obiektów. W dalszej kolejności metoda pozwoli na ocenę zbioru testowego dzięki zastosowaniu algorytmów porównywania wielowymiarowych map wektorowych. Celem działania przyjętej metody jest rozpoznawanie zmian zdrowotnych roślin na podstawie wykonanych zdjęć. Najprostszym podejściem jest określenie wskaźników opartychna obecnościokreślonej długości fal w badanych próbkach. Metody identyfikacji roślin mogą również polegać na analizie ilościowej histogramów interpretowanych zdjęć w poszczególnych kanałach R, G,B dla światła widzialnego (Kazmi i in. 2014). W naszym podejściu, interpretacji poddane są dane ze zdjęć, przedstawione jako wielowymiarowe zbiory punktów opisanych w skali HSL (Hue, Saturation, Luminance). Pozwoliło to na precyzyjną identyfikację skupień danych charakterystycznych dla badanych defektów.

Skuteczna analiza danych wymaga zastosowania takiego sposobu klasyfikacji, który będzie jednocześnie wydajny i będzie pozwalał na porównywanie uzyskiwanych wyników z dużym zbiorem danych wzorcowych. Wśród metod klasyfikacji dużych zbiorów danych mamy do dyspozycji wiele nowoczesnych podejść, takich jak k-means, class method, SOM (Self - Organizing Map) czy GNG (Growing Neural Gas). O ile metoda k-means zakłada określenie liczby klas, na które dzielimy zbiór, który to parametr nie jest w badanym przypadku znany, to metody SOM i GNG nie determinują tej liczby. Ponadto w przypadku wybranego podejścia można interpretować zidentyfikowane klasy jako wielowymiarowe zbiory wektorów identyfikujące skupienia. Metoda GNG jest wydajniejsza i bardziej dokładna od metody SOM (Clary 2013). Istnieje wiele odmian i adaptacji metody GNG stosowanych w zależności od charakterystyki danych wejściowych lub będących udoskonaleniem metody, m.in. FGNG (Fast Growing Neural Gas) (Mendes i in. 2014), AING, AGiNG. Do naszych badań wybraliśmy implementację metody GNG.

Polska firma Relayonit, we współpracy z Instytutem Hodowli i Aklimatyzacji Roślin PIB w Radzikowie, prowadzi od pewnego czasu prace nad zadaniem pod nazwą ,SSN i teledetekcja w diagnostyce zdrowotności plantacji zbóż”. Celem pracy jest opracowanie innowacyjnego oprogramowania do wykrywania chorób pszenicy, pszenżyta i żyta w skali makro (łan), poprzez: utworzenie bazy danych wzorców chorób na podstawie wykonywanych zdjęć, utworzenie mapy przestrzennej upraw, określającej lokalizację oraz identyfikację chorób na podstawie bazy wzorców, wreszcie stworzenie systemu eksportowania wyników analizy pola $\mathrm{w}$ formatach używanych przez zautomatyzowane maszyny stosowane do precyzyjnego opryskiwania. Ponadto, celem prezentowanych badań było przetestowanie możliwości wykorzystania oprogramowania do analizy obrazu oraz sztucznych sieci neuronowych do detekcji oraz oceny nasilenia fuzariozy kłosów pszenicy. 


\section{Material i Metody}

W badaniach założono poletka pszenicy i pszenżyta porażone następującymi chorobami: rdza żółta, rdza brunatna, mączniak prawdziwy, fuzarioza kłosów, septoriozy liści i plew, w stopniu umożliwiającym pozyskanie danych obrazowych o jakości umożliwiającej analizę obrazu i utworzenie bazy wzorców badanych chorób pszenicy i pszenżyta. W artykule ograniczono się do przedstawienia wyników badań polowych 4 odmian pszenicy jarej porażonych i nieporażonych fuzariozą kłosów. Odmiany różniły się poziomem odporności na fuzariozę kłosów (Góral i Walentyn-Góral 2018), a mianowicie odmiany Nawra i Radocha charakteryzowały się niższą odpornością na porażenie fuzariozą kłosów niż Izera i KWS Torridon. Zakres badań obejmował:

1. opracowanie metodyki wykonywania map porażenia $\mathrm{z}$ wykorzystaniem założenia bazy wzorców odmian bez objawów i z objawami porażenia.

2. opracowanie oprogramowania składającego się z modułów: przygotowywania i oznaczania wzorców; analizy zbioru testowego; zbierania i udostępniania danych poprzez ekstrakcję obszaru zidentyfikowanego, jako roślina $\mathrm{z}$ obrazu badanego (określenie $\mathrm{m}$. in. parametrów obrazu), przygotowanie wzorców chorób reprezentowanych przez sieć neuronową (określenie liczby neuronów niezbędnej do zaobserwowania artefaktów występujących w zbiorach wejściowym i reprezentującym chorobę), parametryzację sieci neuronowej $\mathrm{z}$ zastosowaniem algorytmu genetycznego (uzyskania m.in. odchylenia sieci od badanego wzorca), ocenę zgodności sfotografowanej próbki z wzorcem choroby (określenie choroby rośliny), określenie formatu danych i stopnia ich kompresji pozwalającego na skuteczne działanie algorytmu.

Badania wykonano stosując następujące kroki:

1. pozyskanie obrazów RGB,

2. transformacja obrazów do skali HSL,

3. obliczenie wzorców w postaci sieci GNG (Growing Neural Gas),

4. obliczenie zgodności wzajemnej zbioru próbek w postaci sieci neuronowych $\mathrm{GnG}$.

\section{Ad 1.}

Metoda polega na identyfikacji artefaktów występujących na roślinach, obserwowanych w spektrum światła widzialnego. Część objawów kwalifikowała się do rozpoznawania tą metodą, część była trudniej rozpoznawalna. Skuteczność metody była wyższa jeżeli stosowana rozdzielczość zdjęć pozwalała na odróżnienie w pojedynczych pikselach artefaktów wyróżniających objawy chorobowe. Do robienia zdjęć użyto aparatu fotograficznego Canon EOS 60D.

Zdjęcia zostały wykonane w rozdzielczości $4000 / 3000$ px z wysokości 2 metrów a następnie przetworzone $\mathrm{w}$ celu obniżenia rozdzielczości do $1 \mathrm{~mm}$ powierzchni fotografowanej na piksel oraz oznaczone odmianą i oznaczeniem poletka doświadczalnego.

\section{Ad. 2}

Obrazy zapisane bez kompresji stratnej $\mathrm{w}$ formacie BMP, zostały przekonwertowane do formatu $\mathrm{z}$ ośmiobitową reprezentacją koloru (8 bitów/kolor). Przy pomocy oprogramowania dostarczonego nieodpłatnie przez firmę Andromeda CVC Lab (Crops Vegetation Control Lab), dokonano konwersji obrazów do skali HSL (Hue, Saturation, Luminance). Parametry H i S transponowano na skalę liczb naturalnych w zakresie 0-320. Parametr L - jasność, przekonwertowano na skalę 0-32, aby zmniejszyć znaczenie jasności punktów w przeprowadzonej analizie.

\section{Ad. 3}

Dla uzyskanych w kroku 2 próbek wytworzono reprezentacje w postaci sieci neuronowych GNG. Jako przestrzeń zbioru wejściowego zostały określone przestrzenie liczb rzeczywistych odpowiadające wcześniej przygotowanym parametrom HSL. Punktami próbkowania były pełne zbiory obrazów przekonwertowanych do skali HSL, a w trakcie treningu próbkowanie obrazu było dokonywane metodą losową z eliminacją powtórzeń dla punktów zbioru wejściowego, przy 40 iteracjach całego zbioru.

W wyniku klasyfikacji próbek uzyskano 240 wzorców, z których wyliczono wzorce bazowe dla każdego poletka na podstawie serii 10 zdjęć. W efekcie uzyskano 6 wzorców dla każdej odmiany (tabele 1-4).

\section{Ad. 4}

Wszystkie próbki dla których wytworzono reprezentację GNG w kroku 3, zostały potraktowane jako zbiór testowy. Dokonano dwóch analiz; porównania klasyfikacji w odniesieniu do wzorców tej samej odmiany pszenicy (tabele 1-4). Wyniki obliczane były metodą wyliczenia średniej dla sum odległości każdego kolejnego punktu zbioru badanego względem najbliższego punktu zbioru 
wzorcowego, gdzie jako odległość rozumiemy odległość sferyczną w trójwymiarowej przestrzeni liczb rzeczywistych (dla zbiorów przygotowanych jak w pkt 2).

\section{Wyniki i Dyskusja}

W tabelach 1-4 przedstawiono wyniki badań przeprowadzonych dla 4 odmian pszenicy jarej. Wartości w tabelach, to rzeczywiste dane wynikowe z analizy z wykorzystaniem oprogramowania CVC Lab. Są to sumy odchyleń wektorowych pomiędzy najbliższymi neuronami w przestrzeni 3 wymiarów. Każdy wzorzec i próbka reprezentowane są przez 1000 neuronów sieci. Wszystkie zdjęcia były robione w tym samym okresie wegetacyjnym, na wykłoszonych odmianach pszenicy. Mniejsze wartości liczb wskazują na większą zgodność próbek z przyjętymi wzorcami.

Tabela 1.

Wyniki badań zgodności próbek z wzorcami dla pszenicy jarej "Izera".

Table 1

Results of tests for compliance of samples with standards for spring wheat variety "Izera".

\begin{tabular}{l|ccc|c|ccc}
\hline \multirow{2}{*}{ L.p. } & \multicolumn{3}{|c|}{$\begin{array}{c}\text { Wzorce Izera } \\
\text { Próbka K }\end{array}$} & \multirow{2}{*}{ L.p. } & \multicolumn{3}{|c}{ Wzorce Izera } \\
\cline { 2 - 3 } & $\mathrm{K}$ & $\mathrm{P} 1$ & $\mathrm{P} 2$ & & $\mathrm{~K}$ & $\mathrm{P} 1$ & $\mathrm{P} 2$ \\
\hline 1. & 3583 & 4429 & 4550 & 11. & 3778 & 3513 & 3498 \\
2. & 3727 & 4209 & 4425 & 12. & 4301 & 3698 & 3434 \\
3. & 3443 & 3840 & 3959 & 13. & 3832 & 3336 & 3318 \\
4. & 3420 & 3931 & 4200 & 14. & 3715 & 3103 & 3241 \\
5. & 3390 & 4034 & 4240 & 15. & 3902 & 3439 & 3392 \\
6. & 3532 & 4771 & 4809 & 16. & 4202 & 3632 & 3689 \\
7. & 3419 & 4500 & 4588 & 17. & 4490 & 3702 & 3899 \\
8. & 3533 & 4623 & 4693 & 18. & 3990 & 3514 & 3353 \\
9. & 3442 & 3994 & 4311 & 19. & 4302 & 3366 & 3464 \\
10. & 3407 & 4021 & 4593 & 20. & 4655 & 3523 & 3478 \\
\hline$\dot{\mathbf{x}}$ & $\mathbf{3 4 9 0}$ & $\mathbf{4 2 3 5}$ & $\mathbf{4 4 3 7}$ & $\dot{\mathbf{x}}$ & $\mathbf{4 1 1 7}$ & $\mathbf{3 4 8 0}$ & $\mathbf{3 4 7 7}$ \\
$\mathbf{6}$ & $\mathbf{1 0 0}$ & $\mathbf{3 0 6}$ & $\mathbf{2 4 6}$ & $\mathbf{6}$ & $\mathbf{3 0 4}$ & $\mathbf{1 7 6}$ & $\mathbf{1 8 1}$ \\
\hline$\dot{x}-$ średnia arytmetyczna; & &
\end{tabular}

Oznaczenia:

W kolumnach poletka wzorcowe: K-roślin zdrowych, P1 i P2-roślin porażonych fuzarioza,

$w$ wierszach - próbki porównywane: roślin zdrowych (próbka K) i roślin porażonych (próbka P).

Tabela 2

Table 2

Wyniki badań zgodności próbek z wzorcami dla pszenicy jarej „Nawra”.

Results of tests for compliance of samples with standards for spring wheat variety "Nawra".

\begin{tabular}{l|ccc|c|ccc}
\hline \multirow{2}{*}{ L.p. } & \multicolumn{3}{|c|}{ Wzorce Nawra } & \multirow{3}{*}{ Próbka K } & \multicolumn{3}{|c}{ Wzorce Nawra } \\
\cline { 2 - 3 } & $\mathrm{K}$ & $\mathrm{P} 1$ & $\mathrm{P} 2$ & & $\mathrm{~K}$ & $\mathrm{P} 1$ & $\mathrm{P} 2$ \\
\hline 1. & 3530 & 8801 & 9206 & 11. & 8576 & 3738 & 3545 \\
2. & 3619 & 9112 & 10893 & 12. & 8950 & 3851 & 3389 \\
3. & 3610 & 9179 & 9548 & 13. & 10668 & 3584 & 3586 \\
4. & 3417 & 8923 & 10201 & 14. & 11404 & 3939 & 3684 \\
5. & 3418 & 8826 & 9978 & 15. & 9289 & 3554 & 3246 \\
6. & 3351 & 10216 & 10458 & 16. & 10148 & 3614 & 3653 \\
7. & 3572 & 9282 & 10168 & 17. & 9109 & 3723 & 3702 \\
8. & 3624 & 8781 & 10662 & 18. & 9065 & 3769 & 3290 \\
9. & 3549 & 9039 & 9644 & 19. & 10142 & 3625 & 3346 \\
10. & 3433 & 8885 & 9744 & 20. & 9282 & 3775 & 3254 \\
\hline$\dot{\mathbf{x}}$ & $\mathbf{3 5 1 2}$ & $\mathbf{9 1 0 4}$ & $\mathbf{1 0 0 5 0}$ & $\dot{\mathbf{x}}$ & $\mathbf{9 6 6 3}$ & $\mathbf{3 7 1 7}$ & $\mathbf{3 4 6 9}$ \\
$\mathbf{6}$ & $\mathbf{9 4}$ & $\mathbf{4 0 4}$ & $\mathbf{5 0 2}$ & $\mathbf{6}$ & $\mathbf{8 4 5}$ & $\mathbf{1 1 7}$ & $\mathbf{1 7 4}$ \\
\hline
\end{tabular}


Wyniki badań zgodności próbek z wzorcami dla pszenicy jarej "Radocha”. Results of tests for compliance of samples with standards for spring wheat variety "Radocha".

\begin{tabular}{|c|c|c|c|c|c|c|c|}
\hline \multirow[t]{2}{*}{ L.p. } & \multicolumn{3}{|c|}{$\begin{array}{c}\text { Wzorce Radocha } \\
\text { Próbka K }\end{array}$} & \multirow[t]{2}{*}{ L.p. } & \multicolumn{3}{|c|}{$\begin{array}{c}\text { Wzorce Radocha } \\
\text { Próbka P }\end{array}$} \\
\hline & $\mathrm{K}$ & P1 & P2 & & $\mathrm{K}$ & P1 & P2 \\
\hline 1. & 3399 & 9988 & 9203 & 11. & 8576 & 3738 & 3409 \\
\hline 2. & 3689 & 10933 & 10807 & 12. & 8950 & 3851 & 3589 \\
\hline 3. & 3489 & 9633 & 9477 & 13. & 10668 & 3940 & 3468 \\
\hline 4. & 3523 & 9684 & 10237 & 14. & 11404 & 3799 & 3333 \\
\hline 5. & 3254 & 10602 & 9705 & 15. & 10465 & 3626 & 3652 \\
\hline 6. & 3595 & 10113 & 10634 & 16. & 9989 & 3830 & 3557 \\
\hline 7. & 3307 & 10060 & 10282 & 17. & 9237 & 3869 & 3651 \\
\hline 8. & 3306 & 9818 & 9531 & 18. & 9301 & 3787 & 3658 \\
\hline 9. & 3652 & 10087 & 10060 & 19. & 9318 & 3606 & 3403 \\
\hline 10. & 3293 & 10568 & 9813 & 20. & 10548 & 3885 & 3648 \\
\hline$\dot{\mathbf{x}}$ & 3485 & 10149 & 9975 & $\dot{\mathbf{x}}$ & 9846 & 3793 & 3537 \\
\hline 6 & 152 & 403 & 494 & 6 & 858 & 103 & 117 \\
\hline
\end{tabular}

Tabela 4

Wyniki badań zgodności próbek z wzorcami dla pszenicy jarej „KWS Torridon”.

Table 4 Results of tests for compliance of samples with standards for spring wheat variety "KWS Torridon".

\begin{tabular}{|c|c|c|c|c|c|c|c|}
\hline \multirow[t]{2}{*}{ L.p. } & \multicolumn{3}{|c|}{$\begin{array}{c}\text { Wzorce KWS Torridon } \\
\text { Próbka K }\end{array}$} & \multirow[t]{2}{*}{ L.p. } & \multicolumn{3}{|c|}{$\begin{array}{c}\text { Wzorce KWS Torridon } \\
\text { Próbka P }\end{array}$} \\
\hline & K & P1 & P2 & & K & P1 & P2 \\
\hline 1. & 3338 & 4826 & 3866 & 11. & 6727 & 3796 & 4059 \\
\hline 2. & 3317 & 4711 & 4441 & 12. & 7317 & 4059 & 3757 \\
\hline 3. & 3892 & 5229 & 4811 & 13. & 5218 & 4218 & 4181 \\
\hline 4. & 3629 & 5049 & 4766 & 14. & 6136 & 3962 & 3998 \\
\hline 5. & 3406 & 5064 & 4503 & 15. & 6370 & 3848 & 3833 \\
\hline 6. & 3456 & 5015 & 4688 & 16. & 5826 & 4218 & 3994 \\
\hline 7. & 3523 & 5075 & 4434 & 17. & 6082 & 4223 & 4023 \\
\hline 8. & 3362 & 4956 & 4464 & 18. & 6272 & 4212 & 3738 \\
\hline 9. & 3383 & 5134 & 4780 & 19. & 6337 & 3859 & 4045 \\
\hline 10. & 3637 & 5038 & 4243 & 20. & 5907 & 3868 & 3979 \\
\hline$\dot{\mathbf{x}}$ & 3494 & 5100 & 4500 & $\dot{\mathbf{x}}$ & 6219 & 4026 & 3961 \\
\hline $\boldsymbol{\sigma}$ & 171 & 320 & 275 & б & 528 & 170 & 134 \\
\hline
\end{tabular}

$\mathrm{W}$ tabeli 1 , porównując $\mathrm{z}$ wzorcami roślin zdrowych (próbka K) zdjęcia roślin porażonych, uzyskujemy wyraźnie wyższe wartości liczb dla poletek wzorcowych P1 i P2 od liczb uzyskanych dla poletka wzorcowego $\mathrm{K}$. W pierwszym przypadku są to średnie 4235 oraz 4437 w drugim średnia 3490 przy odchyleniach standardowych od wartości średniej w granicach $2-5 \%$. Porównując z wzorcami roślin porażonych (próbka P) zdjęcia roślin porażonych, uzyskano niższe wartości liczb (średnie 3480 i 3477) niż dla zdjęć roślin zdrowych (średnia 4117 przy odchyleniu standardowym $5-7 \%)$. Wyniki zbliżone uzyskano dla pszenicy KWS Torridon. Przy porównaniu zdjęć roślin zdrowych z wzorcami roślin porażonych oraz roślin porażonych $\mathrm{z}$ wzorcami roślin zdrowych, znacznie większe wartości uzyskano dla odmian Nawra i Radocha. Wynika to ze zróżnicowanej odporności badanych odmian pszenicy na porażenie i jest zgodne z oczekiwaniami. Znaczne różnice są widoczne na zdjęciach zdrowych i porażonych roślin odmiany Nawra (Rys. 1-2). Z kolei, nieznaczne różnice są zauważalne na zdrowych i porażonych roślinach odmiany Izera (Rys. 3-4). 


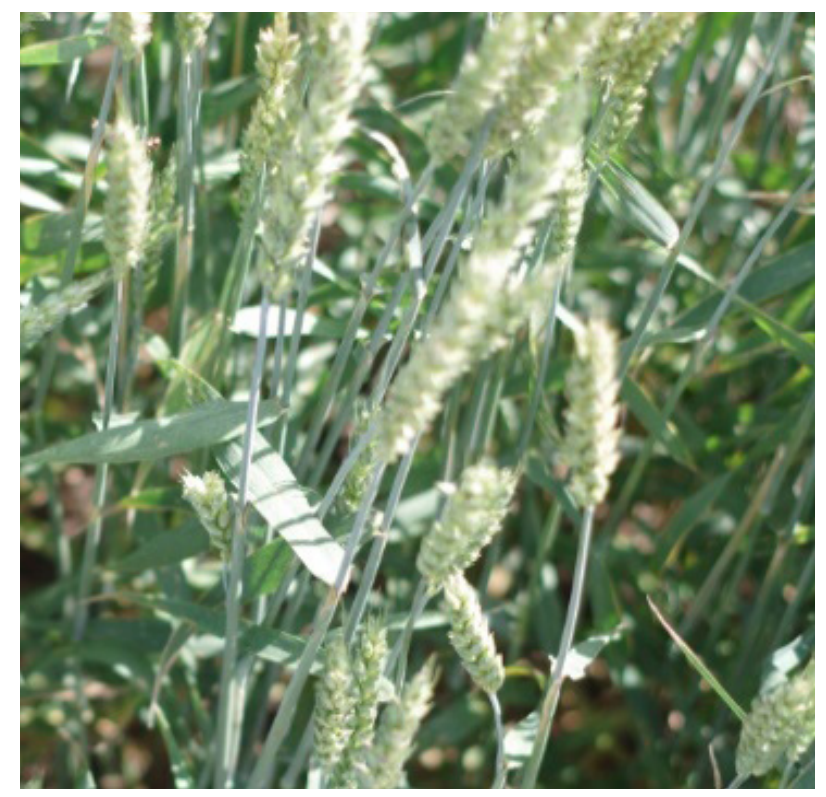

Rys. 1. Pszenica jara odmiana 'Nawra' zdrowa

Fig. 1. Spring wheat variety 'Nawra' healthy

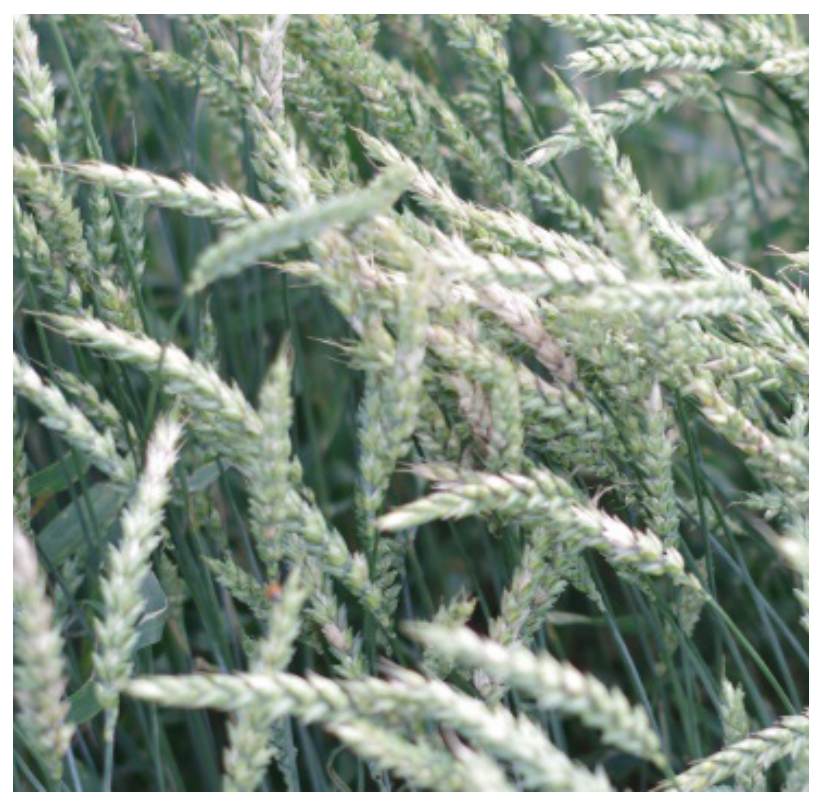

Rys. 3. Pszenica jara odmiana 'Izera' zdrowa

Fig. 3. Spring wheat variety 'Izera' healthy

Zdjęcia były wykonywane na poletkach o różnym stopniu porażenia fuzariozą kłosów. Rośliny porażone, nie były usytuowane na poletkach równomiernie i różna była ich liczba. Wyniki badań dla poszczególnych wzorców były zbliżone. Zmienność badanych populacji była niska i wahała się w granicach od 3 do $10 \%$.

Uzyskane wyniki wskazują na możliwość wykrywania $\mathrm{w}$ łanach pszenicy obszarów rośln porażonych fuzariozą kłosów, przy pomocy użytego w badaniach programu CVC Lab. Można przypuszczać, że podobne wyniki zostaną otrzymane w badaniach pszenżyta i żyta. Wymaga to jednak

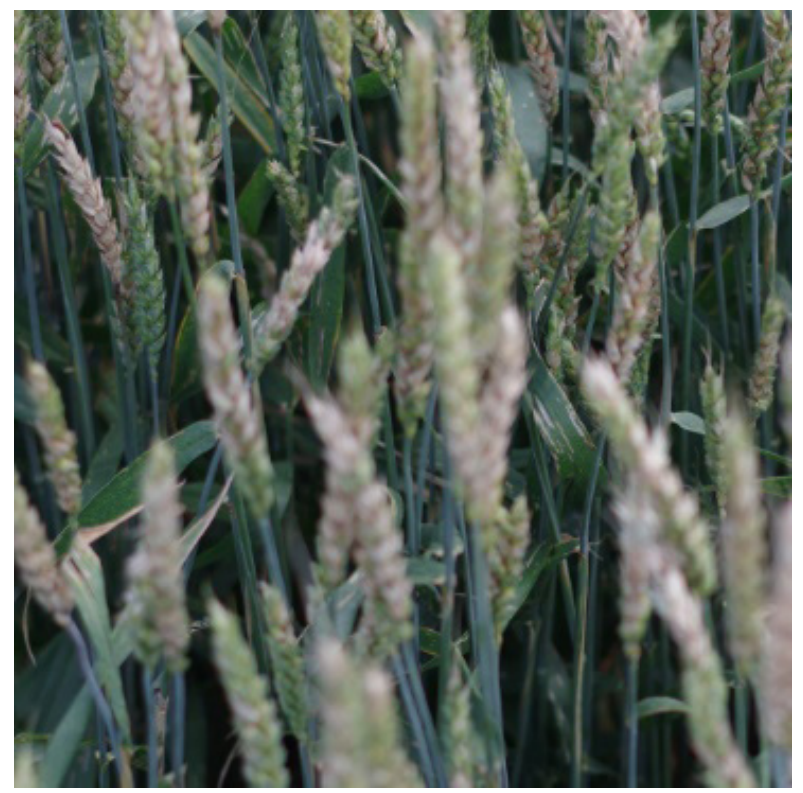

Rys. 2. 'Nawra' porażona Fig. 2. 'Nawra' FHB infected

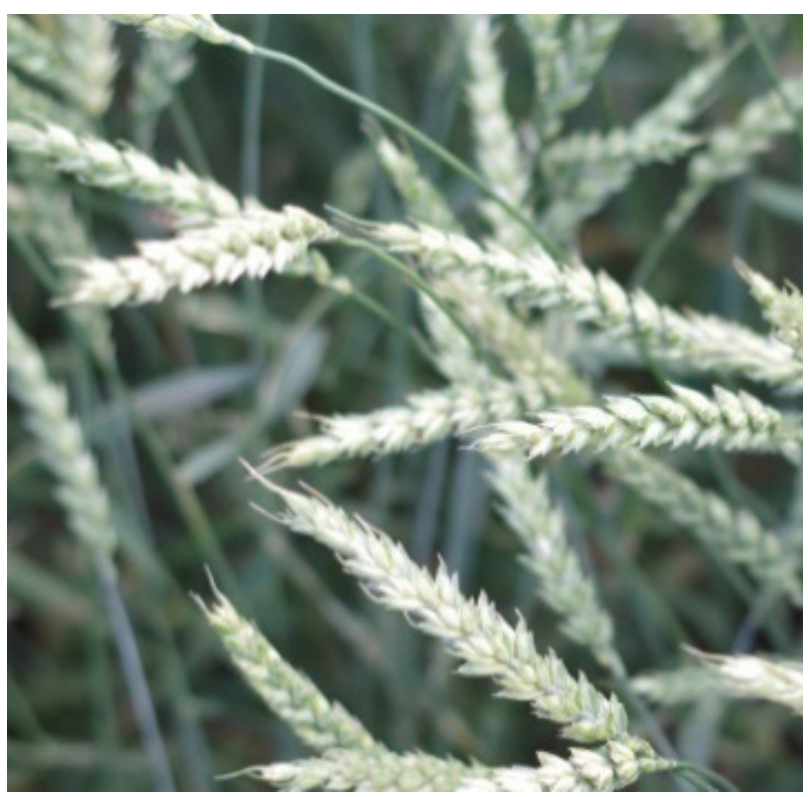

Rys. 4. Izera porażona

Fig. 4. 'Izera' FHB infected

przeprowadzenia rozszerzonych badań z zachowaniem przyjętej metodyki. Należałoby również przeprowadzić badania uwzględniając inne dość powszechnie występujące choroby pszenicy takie jak: rdza żółta, rdza brunatna, mączniak prawdziwy, septorioza liści i plew. Pozytywne wyniki badań pozwolą na sporządzanie map zdrowotności plantacji pszenicy i ewentualnie innych zbóż. Umożliwi to wprowadzenie precyzyjnych oprysków plantacji fungicydami, a co za tym idzie, ograniczenie ich zużycia ze wszystkimi wynikającymi stąd pozytywnymi następstwami opisanymi w pracach Moshou i in., (2011) oraz Song i in. (2015). 
Wprowadzenie opisanej $\mathrm{w}$ tych badaniach technologii ochrony zbóż przed chorobami, wymaga też specjalistycznego sprzętu do robienia odpowiedniej jakości zdjęć badanych plantacji (Kurkute 2018). Mowa tutaj o specjalistycznym dronie wiatrakow$\mathrm{cu}$, wyposażonym w nowoczesne urządzenia techniczne do badań teledetekcyjnych, bardzo wydajne i spełniające wymagania przedstawionej technologii. Uzyskane mapy zdrowotności plantacji zbóż, mogą być wykorzystywane przez aktualnie produkowane supernowoczesne opryskiwacze naziemne, jak też wysokiej jakości drony - multikoptery nadziemne. Potrzebne są też prace nad wykorzystaniem inteligentnej wymiany informacji przez drony w ramach tzw. „roju” dronów do lepszej analizy obszarów o dużej powierzchni. Należy nadmienić, że obecnie demonstrację „roju” dronów przeprowadziły dwa państwa - Chiny oraz USA (Wei i in. 2013). Wykorzystanie ,roju” dronów umożliwia jednoczesne skrócenie czasu wykonania zabiegu na tym samym lub większym obszarze, co w przypadku oblotu pól uprawnych zmniejszy czas wykonywania zabiegów ochronnych.

W podsumowaniunależy podkreślićkonieczność prowadzenia badań i prac rozwojowych od monitoringu stopnia porażenia plantacji roślin uprawnych, w tym zbóż, chorobami do wykonania zabiegów ochronnych. Wyniki takich prac wniosą wkład w opracowanie kompleksowej technologii ochrony zdrowotności plantacji zbóż z udziałem sztucznych sieci neuronowych i teledetekcji, łącznie $\mathrm{z}$ analizą ekonomiczną przedsięwzięcia.

\section{Wnioski}

1. Uzyskane wyniki wskazują na możliwość wykrywania w łanach pszenicy obszarów roślin porażonych fuzariozą kłosów, przy pomocy użytego w badaniach programu CVC Lab.

2. Przy porównaniu zdjęć roślin zdrowych z wzorcami roślin porażonych oraz roślin porażonych z wzorcami roślin zdrowych, znacznie większe wartości uzyskano dla odmian Nawra i Radocha.

3. Zróżnicowanie wartości liczbowych uzyskanych z porównania wzorców roślin zdrowych i porażonych ze zdjęciami poletek roślin zdrowych i porażonych, pozwala na tworzenie map zdrowotności plantacji roślin zbożowych.

4. Uzyskane wyniki wskazują na możliwość wykorzystania sztucznych sieci neuronowych i teledetekcji w precyzyjnej i tańszej ochronie plantacji zbóż środkami chemicznymi.
5. Zastosowane w niniejszej pracy technologie bliskiej teledetekcji i sztucznych sieci neuronowych mogą być wykorzystane do tworzenia map zdrowotności zbóż porażonych innymi chorobami, takimi jak: rdza brunatna, rdza zółta, mączniak prawdziwy, septorioza liści i plew, a także łamliwość źdźbła.

\section{Literatura}

Alchanatis V., Ridel L., Hetzroni A., Yaroslavsky L. 2005. Weed detection in multi-spectral images of cotton fields. Computers and Electronics in Agriculture 47: 243 - 260.

Arseniuk E., Góral T. 2015. Triticale Biotic Stresses - Known and Novel Foes, In Triticale, pp. 83 - 108. Ed F. Eudes. Cham: Springer International Publishing.

Arseniuk E., Fried P.M., Winzeler H., Czembor H.J. 1991. Comparison of resistance of triticale, wheat and spelt to septoria nodorum blotch at the seedling and adult plant stages. Euphytica 55: $43-48$.

Boniecki P. 2005. Wykorzystanie technik neuronowych w praktyce rolniczej. Journal of Research and Applications in Agricultural Engineering, 50: $10-14$.

Clary K., 2013. A Comparison of the Self-Organizing Map and Growing Neural Gas Network in the Context of Optical Character Recognition. Department of Computer Science and Mathematics, Hendrix College, AR, USA: 3 pp.

Figueroa M., Hammond-Kosack K.E. Solomon P.S. 2018. A review of wheat diseases - a field perspective. Mol. Plant Pathol. 19: 1523 - 1536.

Frączek J.2005. Cyfrowa analiza obrazu w technice rolniczej, Inżynieria Rolnicza 6, $149-157$.

Góral T., Ochodzki P., Walentyn-Góral, D., Belter J., Majka M., Kwiatek M., Wiśniewska H. 2015. Odporność genotypów pszenicy ozimej na fuzariozę kłosów i akumulację toksyn fuzaryjnych $\mathrm{w}$ ziarnie scharakteryzowana za pomocą różnych typów odporności. Biuletyn IHAR 276: 19 - 37.

Góral T., D. Walentyn-Góral 2018. Zróżnicowanie podatności odmian pszenicy ozimej i jarej na fuzariozę kłosów badanych w latach 2009-2016. Komunikat. Biuletyn IHAR 284: $3-11$.

Hovmøller M.S., Walter S., Bayles R.A., Hubbard A., Flath K., Sommerfeldt N., Leconte M., Czembor P., Rodriguez-Algaba J., Thach T., Hansen J.G., Lassen P., Justesen A.F., Ali S., de Vallavieille-Pope C. 2015. Replacement of the European wheat yellow rust population by new races from the centre of diversity in the near-Himalayan region. Plant Pathology 65: $402-411$.

Jin X., Jie L., Wang S., Qi H.J., Li S.W. 2018. Classifying wheat hyperspectral pixels of healthy heads and Fusarium head blight disease using a deep neural network in the wild field. Remote Sensing 10: 395. 
Kazmi W., Foix S., Alenyà G., Andersen H.J. 2014. Indoor and outdoordepthimagingofleaveswithtime-of-flightandstereo vision sensors: Analysis and comparison. ISPRS Journal of Photogrammetry and Remote Sensing 88: 128 - 146.

Kurkute S.R. 2018. Drones for Smart Agriculture: A Technical Report. International Journal for Research in Applied Science and Engineering Technology, 6: $341-346$.

Łuczycka D. 2016. Rolnictwo XXI wieku - problemy i wyzwania. ISBN 978-83-945311-0-2: 378

Łukawski R., Golka W., 2011. Identyfikacja efektu mieszania gleby w procesie powierzchniowej uprawy z wykorzystaniem dynamicznej analizy obrazu 3D. Problemy Inżynierii Rolniczej 2: 55 - 64 .

Mendes C.A.T., Gattass M., Lopes H., 2014. FGNG: A fast multi-dimensional growing neural gas implementation. Neurocomputing 128: 328 - 340 .

Moshou D., Bravo C., Oberti R., West J.S., Ramon H., Vougioukas S., Bochtis D. 2011. Intelligent multi-sensor system for the detection and treatment of fungal diseases in arable crops. Biosystems Engineering 108: 311 - 321.

Niedbała G., Kurasiak-Popowska D., Kinga Stuper-Szablewska K. and Jerzy Nawracała, 2020. Application of Artificial Neural Networks to Analyze the Concentration of Ferulic Acid, Deoxynivalenol, and Nivalenol in Winter Wheat Grain. Agriculture 10: 127; doi: 10.3390/agriculture10040127.

Nieróbca A., Pudełko R., Kozyra J. 2009. Zastosowanie zdalnych metod $\mathrm{w}$ analizie zachwaszczenia pól testowych. Progress in Plant Protection/Postępy w Ochronie Roślin, 49: 1622 - 1629.

Osowski S. 2000. Sieci neuronowe do przetwarzania informacji. Oficyna Wydawnicza Politechniki Warszawskiej, Warszawa.

Perez A.J., Lopez F., Benlloch J.V., Christensen S. 2000. Colour and shape analysis techniques for weed detection in cereal fields. Computers and Electronics in Agriculture 25: $197-212$.

Piotrowska E. 2003. Badania filmowe bryły glebowej odkształcanej przez wąskie narzędzie uprawowe. Inżynieria Rolnicza 11: $173-178$.
Prandini A., Sigolo S., Filippi L., Battilani P., Piva G. 2009. Review of predictive models for Fusarium head blight and related mycotoxin contamination in wheat. Food Chem Toxicol. 47: $927-31$.

Pudełko R., Kozyra J., Nieróbca A. 2008. Identification of the intensity of weeds in maize plantations based on aerial photographs. Zemdirbyste-Agriculture, 95: $130-134$.

Qiu R., Yang C., Moghimi A., Zhang M., Steffenson B. 2019. Detection of Fusarium Head Blight in Wheat Using a Deep Neural Network and Color Imaging. Remote Sensing 11: 2685.

Rumelhart D., J. L. McClelland, the PDP Research Group. 1986. Parallel Distributed Processing: explorations in the microstructure of cognition. MIT Press, Cambridge.

Sankaran S., Mishra A., Ehsani R., Davis C. 2010. A review of advanced techniques for detecting plant diseases. Computers and Electronics in Agriculture $721-13$.

Skulska M., Skulska M., Makowski Ł. 2003. Zastosowanie sieci neuronowych. Wydawca: Państwowa Wyższa Szkoła Zawodowa w Tarnobrzegu: 8 str.

Song Y., Sun H., Li M., Zhang Q. 2015. Technology Application of Smart Spray in Agriculture: A Review. Intelligent Automation and Soft Computing 21: $319-333$.

Wei Y., Blake M.B., Madey G.R. 2013. An operation-time simulation framework for UAV swarm configuration and mission planning. In: Proceedings of the International Conference on Computational Science, ICCS 2013, Barcelona, Spain, 5 - 7 June, 2013, pp. 1949 - 1958.

Yuan L., Zhang J., Shi Y., Nie C., Wei L., Wang J. 2014. Damage mapping of powdery mildew in winter wheat with high-resolution satellite image. Remote Sensing, 6: $3611-3623$.

Yang L., Gao F., Shang L., Zhan J., McDonald B. A. 2013. Association between virulence and triazole tolerance in the phytopathogenic fungus Mycosphaerella graminicola. PLoS ONE 8(3): e59568. doi:10.1371/journal. pone.00595. 
